\title{
SOCIAL CAPITAL OF THE PUJON KIDUL TOURISM VILLAGE COMMUNITY IN FACING THE COVID-19 PANDEMIC
}

\author{
Pradnya PARAMITHA DEWI \\ Brawijaya University, Engineering Faculty, Urban and Regional Planning Department, Malang, Indonesia, e-mail: paramitha_ta@student.ub.ac.id
}

\author{
Gunawan PRAYITNO*
}

Brawijaya University, Engineering Faculty, Urban and Regional Planning Department, Malang, Indonesia, e-mail: gunawan_p@ub.ac.id

\section{Dian DINANTI}

Brawijaya University, Malang, Engineering Faculty, Urban and Regional Planning Department, Indonesia, e-mail: dinanti@ub.ac.id

\author{
Citation: Paramitha Dewi, P., Prayitno, G., \& Dinanti, D. (2021). SOCIAL CAPITAL OF THE PUJON KIDUL TOURISM \\ VILLAGE COMMUNITY IN FACING THE COVID-19 PANDEMIC. GeoJournal of Tourism and Geosites, 38(4), $1239-1246$. \\ https://doi.org/10.30892/gtg.38431-765
}

\begin{abstract}
The purpose of this study is to analyze the factors and variables that have the most influence on the formation of social capital, analyze the relationship between variables, and describe the condition of community social capital in the face of the Covid-19 pandemic. There are three social capital variables used, including trust, social norms, and social networks. Confirmatory Factor Analysis (CFA), Structural Equation Modeling (SEM), and a literature review were used in this study. The CFA results show that community social capital is formed from 9 factors, where the most influential variable is the trust variable with a value of 0.81 or $66.3 \%$. The results of the SEM analysis show that the relationship of social capital is described through the trust variable, which directly influences social networks and social norms, which will then also affect social networks. Based on the community's social capital and its willingness to collaborate in the fight against the Covid-19 pandemic, we can conclude that the programs developed by the community and the government to combat the Covid-19 outbreak will go off without a hitch.
\end{abstract}

Key words: social capital, trust, social network, norm, covid-19 pandemic

\section{INTRODUCTION}

The tourism village is one of the tourism developments that focus on the community approach. The community approach taken means that tourism development stands firmly for local communities actively involved in every form of development carried out (Supriadi and Roedjinandari, 2017). High community involvement is generally inseparable from the bonds of social capital owned by the community (Trisnanto et al., 2017). According to Putnam (2001), social capital is a social life in which some participants take collective action effectively to achieve common goals. Social capital has a role as a force in responding to situations in the surrounding environment. The response is then transformed into a joint action to utilize the available resources to achieve common goals (Kusumastuti, 2015). Conceptually, social capital can increase cooperation between communities (Nugraha et al., 2021) in building and developing tourist villages in their area, which can then have a positive impact on the community (Tiyasmono et al., 2019). This has been proven by Prayitno et al. (2020), which shows that the existence of social capital can increase community involvement to join Community Base Organizations (CBO) that can provide mutual benefits. In addition, high social capital is considered to have a relationship with community participation which is able to increase village progress (Irawati et al., 2021). One of the tourist villages that has succeeded in utilizing its social capital to build and develop the potential of its village is Pujon Kidul Tourism Village, which is located in Pujon District, Malang Regency. Pujon Kidul Tourism Village is a village that has considerable agricultural potential. However, the existing agricultural potential still does not have an optimal impact on the community's economy. This makes the community begin to explore the existing potential to integrate it with tourism activities.

Tourism activities in Pujon Kidul Tourism Village began to develop in 2012. This activity was pioneered by the village government and some people members of the Tourism Awareness Group (Pokdarwis), consisting of less than 20 people (Primary Survey Results, 2021). Over time, people directly or indirectly involved in village tourism activities have experienced a tremendous increase, which is approximately 45\% of the population (Ira and Muhamad, 2020). This involvement is manifested in mutual assistance to provide attractions, amenities, accessibility, accommodation, and marketing of village tourism activities. The significant community involvement makes the village's leading economy now in the agricultural sector and the tourism sector. The combination of the two sectors also impacts Village Original Income in 2019, which has reached Rp. 2.03 billion, an increase of 65\% from the previous year (SIE Pujon Kidul, 2020). In 2020, the agricultural and tourism sectors of Pujon Kidul Tourism Village were being affected by the Covid-19 pandemic. The existence of the pandemic had to make around 726 tourism workers have to lose their jobs temporarily, and agricultural products become unsold in the market, and selling prices fell by $40 \%$. The impact is also still felt by the community even though tourism activities reopened on August

\footnotetext{
* Corresponding author
} 
15, 2020, including around 250 tourism workers having to be laid off, tourists' purchasing power has decreased, and sales of agricultural products have decreased by around 75\% (Primary Survey Results, 2021). According to Matei et al, (2021), human interaction plays an important role in the tourism sector. The existence of a pandemic can reduce tourist capacity and have an impact on tourism income. In addition, social problems felt by the community include social disorganization due to restrictions on social activities recommended by the government and low public awareness in complying with the Covid-19 health protocol (Primary Survey Results, 2021). Efforts are needed now to overcome the socio-economic problems caused by the Covid-19 pandemic. The Pujon Kidul Tourism Village people had good social capital before the Covid-19 pandemic, and they recognized their potential in building and developing their village. Mutiara et al. (2020), contend that owned social capital and social values should significantly benefit when the situation calls for it. The concept of social capital is perceived to foster strong social cohesion and facilitate collective action (Jacobs and Hofman, 2020). This collaborative action can undoubtedly be used to improve the community's socio-economic conditions. As a result, an in-depth study of the social capital of the Pujon Kidul Tourism Village community in dealing with the Covid-19 pandemic is required.

\section{LITERATURE REVIEW}

At first, the concept of social capital emerged because there was a thought that it was impossible for society to solve problems individually, togetherness and good cooperation were needed to overcome these problems (Syahra, 2003). Social capital according to Bourdieu (1986), is a form of quality relationship among community members that can be a potential source of mutual benefit. Meanwhile, according to Putnam (2001), social capital is a picture of social life in which some participants take collective action effectively to achieve common goals. Thus, social capital refers more to the relationships between individuals that form social networks, norms, and trust. The results of other studies that describe the relationship between elements of social capital include research by Farisa et al. (2019), which shows that social norms and trust are described as having a direct influence on social networks, which will affect the level of community participation. Leliana's research (2017), shows that trust has a direct influence on network formation and norms, which also influence network formation. Zamroni's, research (2018) shows that social networks and social norms directly influence trust, which will also affect community participation. Based on the results of previous studies, it can be seen that trust, social norms, and social networks are the three elements of social capital that have a relationship with each other. Where the three elements have the following explanation:

- Trust is a person's belief that another person is good-natured and hopes that person can do something as expected (Putnam and Goss, 2002). If trust is misused, there will be negative consequences for individuals who are willing to take risks (Kwantes and Kuo, 2021). The higher the level of mutual trust in a community, the higher the possibility for cooperation (Putnam, 2001). According to Huraerah (2008), collective action based on a sense of trust will generally increase community participation, especially in supporting joint progress that can contribute to increasing social capital.

- Social norms are a collection of rules that must be obeyed by the community in a specific area (Suaib, 2017). The most crucial characteristic in a norm is that there is a reciprocal process that will shape social interactions and later help solve joint action problems (Hauberer, 2011). Prayitno et al. (2019) found that norms in the community could increase the social form to reduce poverty.

- Social networks are inter-node ties between individuals or groups that are bound by trust and maintained by norms. Where, within the network, there is also a formed collaboration (Suaib, 2017). The denser the network in a community, the more likely it is to cooperate and achieve common goals (Hauberer, 2011). In addition, the higher the density of social networks can also form a more productive composition of social capital structure (Leon, 2020).

\section{MATERIALS AND METHODS}

\section{Research Variables}

In this study, four objectives are to be achieved, including: (1-2) analyzing the factors and variables that have the most influence on the formation of social capital (Table 1), (3) analyzing the relationship between social capital variables (Table 2), and (4) describing the condition of social capital in the face of the Covid-19 pandemic (Table 3). Therefore, the following are the variables used to obtain all objectives in this study.

Table 1. Variables for the First and Second Goals

\begin{tabular}{|c|c|c|c|}
\hline Goals & Variables & Indicator & Source \\
\hline \multirow{15}{*}{$\begin{array}{l}\text { It } \\
\text { analyzes } \\
\text { the factors } \\
\text { and } \\
\text { variables } \\
\text { that most } \\
\text { influence } \\
\text { the social } \\
\text { capital } \\
\text { formation } \\
\text { of the } \\
\text { Pujon } \\
\text { Kidul } \\
\text { Tourism } \\
\text { Village } \\
\text { community }\end{array}$} & \multirow{7}{*}{ Trust $(\mathrm{K})$} & Level of trust in a fellow community (K1) & (Sidu, 2006); (Farisa et al., 2019) \\
\hline & & Level of trust in people with different cultural backgrounds (K2) & (Farisa et al., 2019) \\
\hline & & Level of trust in village government (K3) & (Sidu, 2006); (Farisa et al., 2019) \\
\hline & & Level of trust in local community leaders (K4) & (Sidu, 2006), (Farisa et al., 2019) \\
\hline & & Level of trust in local religious leaders (K5) & (Farisa et al., 2019; Prayitno et al., 2021) \\
\hline & & Level of trust in village institutions (K6) & (Sidu, 2006) \\
\hline & & Level of trust in information related to the development program to be implemented (K7) & (Farisa et al., 2019) \\
\hline & \multirow{2}{*}{\begin{tabular}{|l|} 
Social \\
Norms (N) \\
\end{tabular}} & Level of adherence to prevailing customary norms (N1) & (Sidu, 2006); (Farisa et al., 2019) \\
\hline & & Attendance level in participating in traditional activities or events (N2) & (Farisa et al., 2019) \\
\hline & \multirow{6}{*}{$\begin{array}{l}\text { Social } \\
\text { Network } \\
\text { (J) }\end{array}$} & Level of willingness to build cooperation to achieve mutual success (J1) & (Sidu, 2006); (Farisa et al., 2019) \\
\hline & & Level of participation in religious activities (J2) & (Farisa et al., 2019) \\
\hline & & Level of participation in community social activities (J3) & (Farisa et al., 2019) \\
\hline & & Level of activity in giving opinions (J4) & (Farisa et al., 2019) \\
\hline & & Level of communication with others (J5) & (Farisa et al., 2019) \\
\hline & & Level of participation in a group or community (J6) & (Farisa et al., 2019) \\
\hline
\end{tabular}


Table 2. Variables for the Third Goal

\begin{tabular}{|l|l|l|l|}
\hline \multicolumn{1}{|c|}{ Goals } & \multicolumn{1}{|c|}{ Variables } & Indicator & Source \\
\hline We are analyzing the & $\bullet$ Trust (K) & & \\
relationship between & $\bullet$ Social & CFA & \\
each social capital & Norms (N) & analysis & (Putnam, \\
variable of the Pujon & $\bullet$ Social & results & \\
Kidul Tourism & Network (J) & & \\
Village community. & & \\
\hline
\end{tabular}

\section{METHOD OF COLLECTING DATA}

This study's data collection methods are divided into two types, namely primary data collection and secondary data collection. Secondary data collection was carried out in two ways, namely through, literature studies and agency studies. Meanwhile, primary

data collection is done through questionnaire data from previous studies, interviews, and observations. The use of this previous research data comes from a thesis study entitled "Social Capital of the Community to Decisions in Collective Actions for the Development of Pujon Kidul Village." The research is research data belonging to Fauzan Roziqin in 2019. The use of the previous questionnaire research data is due to the limitations of researchers to conduct field surveys due to the Covid-19 pandemic who recommends doing social distancing and limiting meetings with other people. Thus, researchers use raw data previously collected to be reprocessed to answer research related to social capital in the face of the Covid-19 pandemic. The use of this raw data is also based on the assumption that the social capital in Pujon Kidul Tourism Village has not changed, considering the time difference is only one year from the previous research. Determination of the number of samples in this study is based on the determination that has been made by previous researchers, namely using Isaac and Michael's table with an error rate of 5\%. The population used is the entire Pujon Kidul Tourism Village community with a total of 1.222 families because the entire community is considered to have participated directly or indirectly to deal with the Covid-19 pandemic. So, based on Isaac and Michael's table, the minimum number of samples used is 275 households (Table 4). The number of samples was further divided into three hamlets, namely Krajan Hamlet, Maron Hamlet, and Tulungrejo Hamlet, by considering the proportion of the number of households in each hamlet.

\section{ANALYSIS METHOD}

There are three analyses used in community social capital research in dealing with the Covid-19 pandemic in the Pujon Kidul Tourism Village. The three analyzes include Confirmatory Factor Analysis (CFA), Structural Equation Modeling (SEM), and literature review. The following is an explanation of the three analyzes used (Figure 1).

- Confirmatory Factor Analysis, or CFA, is an analytical tool used to test the relationship between indicators and constructs and determine whether or not the indicator strongly influences a construct (Santoso, 2014). In this study, CFA is used to analyze the factors and variables that most influence the social capital formation of the Pujon Kidul Tourism Village community. CFA calculations were carried out using the Amos software version 24.

- Structural Equation Modeling, or SEM, is a statistical method that examines the relationship between many variables simultaneously (Collier, 2020). SEM aims to analyze the relationship between social capital variables consisting of trust, social norms, and social networks. This SEM analysis is a follow-up analysis of the results of the CFA fit model. In addition, in this study, SEM analysis was carried out in an exploratory way to find the most suitable model.

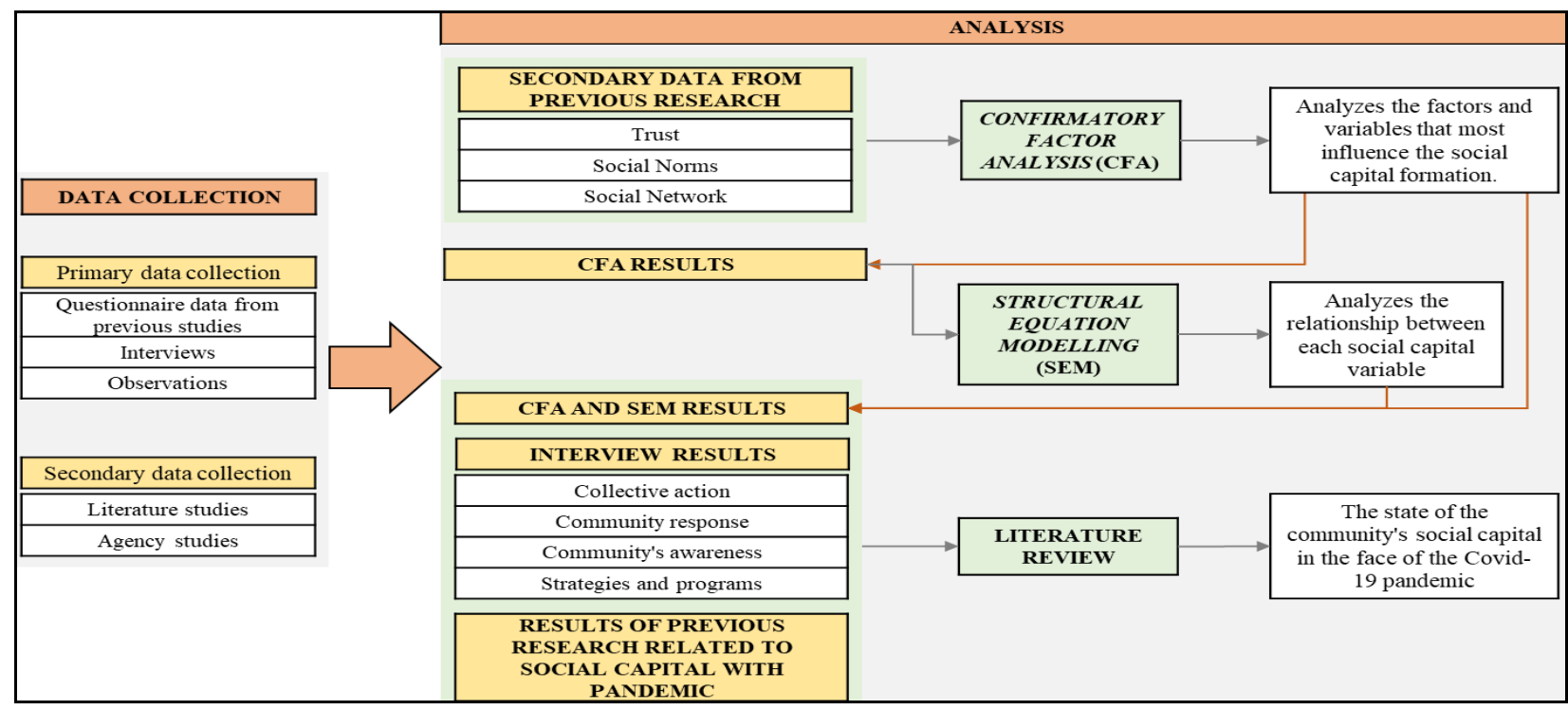

Figure 1. Research Methodology 
- The literature review is an analysis to synthesize information centered on research findings and summarize to conclude the contents of the literature (Setyosari, 2016). In this study, the literature review is used to narratively correlate the relationship of social capital with the Covid-19 pandemic.

\section{RESULTS AND DISCUSSION}

\section{Overview of study area}

Pujon Kidul Tourism Village is one of the villages in Pujon District, Malang Regency, located at a position of $7^{\circ} 21^{\prime}-$ $7^{\circ} 31^{\prime}$ south latitude and $110^{\circ} 10^{\prime}-111^{\circ} 40^{\prime}$ east longitude. Administratively, Pujon Kidul Tourism Village has the following regional boundaries (Pujon Kidul Village Profile, 2019):

North side: Ngroto Village, Pujon Lor Village; East: Pandesari Village, Pujon Lor Village

South side: Forest Area; West: Sukomulyo. Village

Pujon Kidul Tourism Village consists of 3 hamlets: Krajan Hamlet, Maron Hamlet, and Tulungrejo Hamlet. The three hamlets then consisted of $9 \mathrm{RW}$ and $20 \mathrm{RT}$. This village has $330 \mathrm{Ha}$ with the largest land use classification being on undeveloped land use, namely upland and fields by 67\% (Profile of Pujon Kidul Village, 2019).

\section{CHARACTERISTICS OF RESPONDENTS}

The characteristics of respondents in this study consisted of characteristics of respondents based on age, education level, type of work, and total income. The results that have been obtained based on questionnaire activities can be seen in Table 5 .

Based on Table 5, most of the respondents are of productive age with an age range of 21-65 years or 88\%. This indicates that most of the respondents are at the ideal age to work and can be directly involved in any village development program. Meanwhile, based on the characteristics of the education level, it can be seen that most of the respondents, on average, have a basic education level, namely elementary school or equivalent, with a total of 221 respondents or $80 \%$ of respondents. This shows that the respondents in this study still have a low level of education due to the limited economic condition of the community. The low level of existing education can affect the work and income of the community. The higher the respondent's education level, the higher the possibility of getting a decent job and income. Therefore, it can be seen that this low level of education also impacts $42 \%$ of respondents working as farmers with an average income ranging from Rp. 1.500.001 - Rp. 2,000,000. The amount of income is considered small when compared to the Malang Regency Minimum Wage, which is Rp. 3,068,275.36.

Table 5. Characteristics of Respondents (Source: Roziqin, 2019)

\begin{tabular}{|c|c|c|c|}
\hline Characteristics & Category & Total & Percentage \\
\hline \multirow{7}{*}{ Age } & $<26$ & 3 & $1 \%$ \\
\hline & $26-35$ & 24 & $9 \%$ \\
\hline & $36-45$ & 88 & $32 \%$ \\
\hline & $46-55$ & 74 & $27 \%$ \\
\hline & $56-65$ & 54 & $20 \%$ \\
\hline & $>65$ & 32 & $12 \%$ \\
\hline & Total & 275 & $100 \%$ \\
\hline \multirow{6}{*}{$\begin{array}{l}\text { Level of } \\
\text { Education }\end{array}$} & No Formal Education & 4 & $1 \%$ \\
\hline & Primary School & 221 & $80 \%$ \\
\hline & Junior High School & 26 & $9 \%$ \\
\hline & Senior High School & 16 & $6 \%$ \\
\hline & College & 8 & $3 \%$ \\
\hline & Total & 275 & $100 \%$ \\
\hline \multirow{6}{*}{ Type of Work } & Unemployed & 19 & $7 \%$ \\
\hline & Farm Workers & 68 & $25 \%$ \\
\hline & \begin{tabular}{|l|} 
Farmer \\
\end{tabular} & 115 & $42 \%$ \\
\hline & Employees & 50 & $18 \%$ \\
\hline & Entrepreneur & 23 & $8 \%$ \\
\hline & Total & 275 & $100 \%$ \\
\hline \multirow{6}{*}{ Total Income } & $\leq$ Rp. 500.000 & 17 & $7 \%$ \\
\hline & Rp. $500.001-$ Rp. 1.000 .000 & 66 & $21 \%$ \\
\hline & Rp. 1.000.001-Rp.1.500.000 & 115 & $18 \%$ \\
\hline & Rp. 1.500.001-Rp. 2.000 .000 & 51 & $27 \%$ \\
\hline & > Rp. 2.000.001 & 26 & $27 \%$ \\
\hline & Total & 275 & $100 \%$ \\
\hline
\end{tabular}

Table 6. Results of Response Frequency Distribution (Source: Roziqin, 2019)

\begin{tabular}{|c|c|c|c|c|c|c|c|}
\hline Variables & Indicator & STS & TS & B & S & SS & Mode \\
\hline \multirow{4}{*}{ (K) } & $\mathrm{K} 1$ & $0 \%$ & $1 \%$ & $14 \%$ & $21 \%$ & $64 \%$ & 5 \\
\cline { 2 - 8 } & $\mathrm{K} 2$ & $0 \%$ & $1 \%$ & $9 \%$ & $23 \%$ & $67 \%$ & 5 \\
\cline { 2 - 8 } & $\mathrm{K} 3$ & $0 \%$ & $3 \%$ & $14 \%$ & $27 \%$ & $56 \%$ & 5 \\
\cline { 2 - 8 } & $\mathrm{K} 4$ & $0 \%$ & $1 \%$ & $8 \%$ & $38 \%$ & $53 \%$ & 5 \\
\cline { 2 - 8 } & $\mathrm{K} 5$ & $0 \%$ & $1 \%$ & $10 \%$ & $39 \%$ & $50 \%$ & 5 \\
\cline { 2 - 8 } & $\mathrm{K} 6$ & $0 \%$ & $5 \%$ & $12 \%$ & $38 \%$ & $45 \%$ & 5 \\
\cline { 2 - 8 } & $\mathrm{K} 7$ & $0 \%$ & $3 \%$ & $16 \%$ & $40 \%$ & $42 \%$ & 5 \\
\hline \multirow{4}{*}{ (N) } & $\mathrm{N} 1$ & $0 \%$ & $3 \%$ & $12 \%$ & $27 \%$ & $58 \%$ & 5 \\
\cline { 2 - 8 } & $\mathrm{N} 2$ & $0 \%$ & $6 \%$ & $11 \%$ & $30 \%$ & $53 \%$ & 5 \\
\hline \multirow{4}{*}{$(J)$} & $\mathrm{J} 1$ & $0 \%$ & $0 \%$ & $12 \%$ & $36 \%$ & $51 \%$ & 5 \\
\cline { 2 - 8 } & $\mathrm{J} 2$ & $0 \%$ & $1 \%$ & $7 \%$ & $35 \%$ & $57 \%$ & 5 \\
\cline { 2 - 8 } & $\mathrm{J} 3$ & $0 \%$ & $1 \%$ & $7 \%$ & $40 \%$ & $51 \%$ & 5 \\
\cline { 2 - 8 } & $\mathrm{J} 4$ & $0 \%$ & $1 \%$ & $8 \%$ & $46 \%$ & $45 \%$ & 4 \\
\cline { 2 - 7 } & $\mathrm{J} 5$ & $1 \%$ & $0 \%$ & $7 \%$ & $42 \%$ & $50 \%$ & 5 \\
\cline { 2 - 8 } & $\mathrm{J} 6$ & $0 \%$ & $1 \%$ & $8 \%$ & $46 \%$ & $45 \%$ & 4 \\
\hline
\end{tabular}

Table 7. The goodness of Fit CFA Source: Analysis result, 2021

\begin{tabular}{|l|c|c|c|c|}
\hline No & $\begin{array}{c}\text { The goodness } \\
\text { of Fit Index }\end{array}$ & Cut off Value & Result & Note \\
\hline 1. & Chi-Square & $\begin{array}{c}<\alpha . \mathrm{df} \\
(\alpha=0,005)\end{array}$ & $\begin{array}{c}<45,56(\mathrm{df}= \\
24) 29,228\end{array}$ & Good Fit \\
\hline 2. & Probability & $>0,05$ & 0,212 & Good Fit \\
\hline 3. & CMIN/DF & $<2$ & 1,218 & Good Fit \\
\hline 4. & GFI & $\geq 0,90$ & 0,977 & Good Fit \\
\hline 5. & AGFI & $\geq 0,90$ & 0,957 & Good Fit \\
\hline 6. & CFI & $\geq 0,90$ & 0,982 & Good Fit \\
\hline 7. & TLI & $\geq 0,90$ & 0,988 & Good Fit \\
\hline 8. & RMSEA & $\leq 0,08$ & 0,028 & Good Fit \\
\hline
\end{tabular}

\section{DESCRIPTIVE STATISTICS OF SOCIAL CAPITAL}

The descriptive statistics of social capital in this study aim to describe the respondents' statements on each of the indicators contained in the dimensions of the construct of social capital. There are three dimensions of social capital, including trust (K), social norms $(\mathrm{N})$, and social networks $(\mathrm{J})$. The results of respondents' answers to each indicator are shown in Table 6 . Based on Table 6 it can be seen that most of the respondents answered Strongly Agree (SS) on the indicator statements given at the time of the questionnaire. 13 indicators have a mode value of 5 or Strongly Agree (SS) on the given statement. Meanwhile, the other two indicators have a four or Agree (S) mode value on the given statement. 


\section{CONFIRMATORY FACTOR ANALYSIS (CFA)}

CFA is an analytical tool used to analyze the relationship between indicators (manifest variables) and constructs (latent variables). In this study, the CFA used is a second-order variable (Second Order Variable). The reason for conducting this second-level CFA analysis is that social capital is the first latent variable. In contrast, trust $(\mathrm{K})$, social norms $(\mathrm{N})$, and social network (J) are the second latent variables (dimensions) that contribute to the first latent variable. The three dimensions of the social capital construct are dimensions that cannot be measured directly, requiring several indicators. In this study, there are 15 indicators to measure each dimension of the social capital construct. The final result of the run model that has been carried out through the Amos software version 24 is shown in the Figure 2. Based on Figure 2 it can be seen that the model has met the requirements. The remaining nine indicators have significant values with C.R. 1.967 and p-value 0.05 and have been declared valid with a loading factor value of 0.50 . The nine indicators declared effective and valid mean that these indicators have measured the dimensions of the constructs they have appropriately formed. Therefore, no indicators need to be discarded and can then carry out a model feasibility test or commonly referred to as goodness of fit (Gofi).

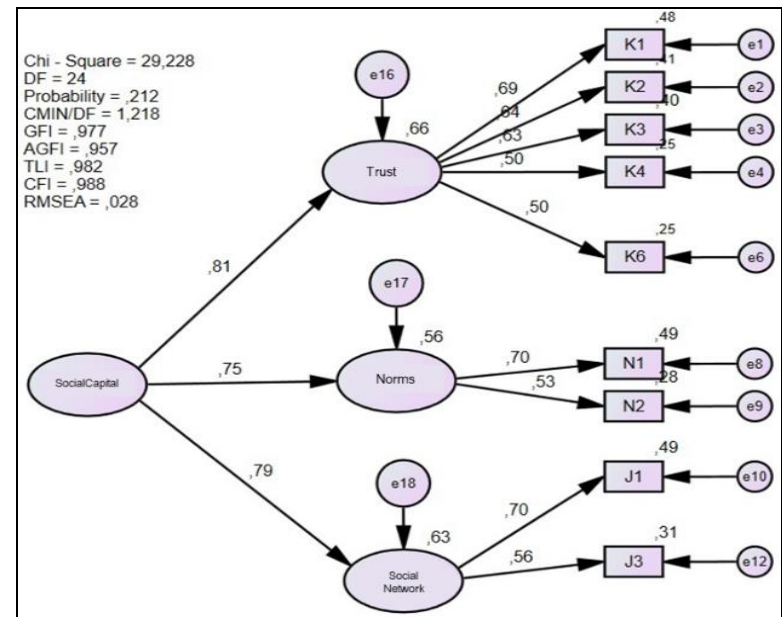

Figure 2. Results of the CFA Final Model

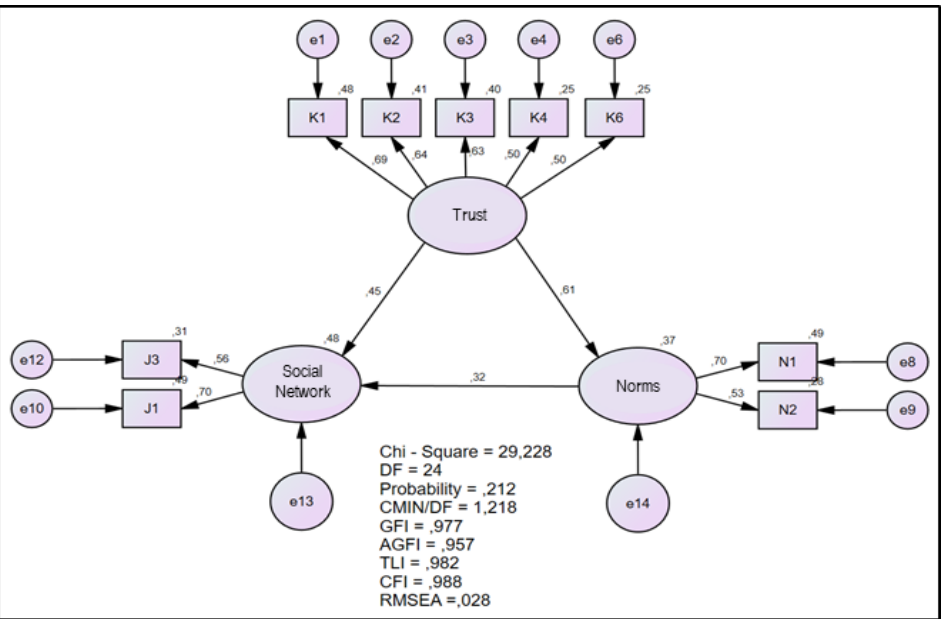

Figure 3. Model Fit SEM

Based on Table 7 It can be seen that the model is fit because it already has a GOFI value that is following the specified limit value. Therefore, this model can be studied and used for the following analysis, namely SEM analysis. Based on Figure 2 it can be seen that nine indicators are forming the dimensions of the social capital construct of the Pujon Kidul Tourism Village community. Therefore, the nine indicators can be described as a measurement model equation as follows:

$\mathrm{K} 1=0.69$ Trust $+\mathrm{e} 1 ; \mathrm{K} 2=0.64$ Trust $+\mathrm{e} 2 ; \mathrm{K} 3=0.63$ Trust $+\mathrm{e} 3 ; \mathrm{K} 4=0.50$ Trust $+\mathrm{e} 4 ; \mathrm{K} 6=0.50$ Trust $+\mathrm{e} 6 ;$

$\mathrm{N} 1=0.70$ Norm + e8; N2 $=0.53$ Norm + e9; J1 $=0.70$ Social Network + e10; J3 $=0.56$ Social Networks + e12

As can be seen from the measurement equation above, the dimension of trust is composed of five components: trust in others (K1) with a value of 0.69 , trust in people from diverse cultural backgrounds (K2) with a value of 0.64 , trust in the village government (K3) with a value of 0.63 , and trust in community leaders (K4) with a value of 0.50 . The trust in fellow community members (K1) has the highest value, with a loading factor of 0.69 . This is consistent with the findings of community interviews, which revealed a strong belief in their neighbors in their immediate environment. A strong sense of trust enables people to look after one another and carry out all activities collaboratively.

Next are the factors that form social norms in the Pujon Kidul Tourism Village community. Based on the measurement model, it can be seen that the social norms of society are formed from two factors, namely the level of obedience to the prevailing norms (N1) with a value of 0.70 and the level of attendance in participating in traditional activities or events (N2) with a value of 0.53 . Thus, it can be seen that the indicator value at the level of community compliance with applicable norms (N1) in Pujon Tourism Village has the most significant value with a loading factor value of 0.70 . This is following the living conditions of the people of Pujon Kidul Tourism Village, who still hold tightly to the traditions of their ancestors, thus making the community still highly uphold the applicable norms.

In the last dimension, namely social networks, it can be seen that two factors are forming social networks in the Pujon Kidul Tourism Village community. The two factors include the level of willingness to work together to achieve mutual success (J1) with a value of 0.70 and the level of participation in community social activities (J3) with a value of 0.56. So based on these results, it can be seen that the social network in the community is formed due to the willingness of each individual to work together and the high community participation in social activities. Social activities in the Pujon Kidul Tourism Village include social gathering activities, sports, arts, and village rehearsals. Existing social activities make it a place for the community to stay in touch and form stronger relationships between communities. Apart from identifying the factors contributing to the dimensions of the social capital construct, this CFA analysis can also determine the magnitude of each dimension's influence on the formation of social capital constructs, including trust, social norms, and social networks. The magnitude of this influence can be determined by the Squared Multiple Correlation coefficient $\left(\mathrm{R}^{2}\right)$. The greater the $\mathrm{R}^{2}$ value, the more certain it is that these dimensions can accurately measure social capital. To illustrate the value of $\mathrm{R}^{2}$, the dimension with the most significant influence on the formation of social capital is the trust variable, which has a value of 0.81 or 66.3 percent. While social norms have a 55.5 percent influence, and social networks have a 62.9 percent influence. 


\section{STRUCTURAL EQUATION MODELING (SEM)}

Structural Equation Modeling (SEM) analysis aims to analyze the relationship between the dimensions of the social capital construct of the Pujon Kidul Tourism Village community, which consists of trust, social norms, and social networks. This analysis is a follow-up analysis of the results of the previous CFA fit model. In this study, SEM analysis was carried out in an exploratory way to find the most suitable model in describing the relationship between the dimensions of the social capital construct of society. The relationship that will be described serves to determine the causal relationship that occurs and the magnitude of the strength of the direct or indirect relationship between variables. Three possible fit models can be generated to describe this relationship, including:

1.The first model is described through the belief pathway coefficient (exogenous variable), which directly influences social networks and social norms (endogenous variable). Meanwhile, the path coefficient for social norms is also described as directly influencing social networks.

2. In the second model, it is described that the social network Path coefficient (exogenous variable) has a direct influence on beliefs and social norms (endogenous variable). Meanwhile, the path coefficient for trust is also described as having a direct influence on social norms.

3. In the third model, it is described that the path coefficient of social norms (exogenous variables) has a direct influence on social networks and trust (endogenous variables). Meanwhile, the path coefficient for social networks is also described as having a direct influence on trust.

The three models were then tested for significance and model feasibility tests through Goodness of Fit to determine the most suitable model. The comparison of the test results of the three models that have been carried out can be seen in the Table 8. As illustrated in Table 8, the three models are acceptable for describing the relationship between the dimensions of the Pujon Kidul Tourism Village community's social capital construct. The most suitable and fit model was then chosen from the three models. Models with a C.R. of 1.96 or greater are considered to be significant. Similarly, if the p-value in the model is 0.05 or if more path coefficients have a $* * *$ sign, the model is more significant. Thus, based on this explanation, the first model is the most significant model for describing the relationship between society's social capital construct dimensions. Based on Figure 3 it can be seen that the first model is a fit model, which is indicated by the chi-square, probability, and CMIN/DF values that have met the requirements. The model can be declared fit in this first model if it has a small chisquare value, which is less than 36.42 , a probability value $>0.05$, and a CMIN/DF value $<2$. Meanwhile, the chi-square value in this model is 29,23 , the probability value is 0.21 , and the CMIN/DF value is 1.22 .

Table 8. Comparison of Model Significance

Test Results (Source: Analysis result, 2021)

\begin{tabular}{|c|l|r|r|l|l|}
\hline No & \multicolumn{1}{|c|}{ Connection } & C.R. & \multicolumn{1}{|l|}{ P } & Loading Factor & Note \\
\hline \multirow{3}{*}{$\begin{array}{c}\text { Model } \\
1\end{array}$} & Trust $\rightarrow$ Social Network & 3,345 & $* * *$ & 0,454 & Significant \\
\cline { 2 - 6 } & Trust $\rightarrow$ Norms & 5,948 & $* * *$ & 0,607 & Significant \\
\cline { 2 - 6 } & Norms $\rightarrow$ Social Network & 2,073 & 0,038 & 0,316 & Significant \\
\hline \multirow{3}{*}{$\begin{array}{c}\text { Model } \\
2\end{array}$} & Social Network $\rightarrow$ Trust & 5,016 & $* * *$ & 0,646 & Significant \\
\cline { 2 - 6 } & Social Network $\rightarrow$ Norm & 2,095 & 0,036 & 0,342 & Significant \\
\cline { 2 - 6 } & Trust $\rightarrow$ Norm & 2,655 & 0,008 & 0,386 & Significant \\
\hline \multirow{2}{*}{$\begin{array}{c}\text { Model } \\
3\end{array}$} & Norm $\rightarrow$ Trust & 2,372 & 0,018 & 0,346 & Significant \\
\cline { 2 - 6 } & Norm $\rightarrow$ Social Network & 4,291 & $* * *$ & 0,591 & Significant \\
\cline { 2 - 6 } & Social Network $\rightarrow$ Trust & 2,940 & 0,003 & 0,441 & Significant \\
\hline
\end{tabular}

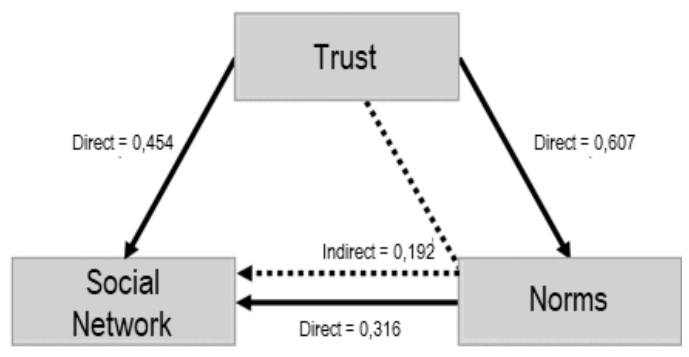

Figure 4. Relationship Between Social Capital Variables (Source: Analysis result, 2021)

According to the first model, trust directly affects two variables, namely social networks and social norms, and social norms variables also directly affect social networks. Therefore, the direct, indirect, and total effects of a variable on other variables must be analyzed to determine the magnitude of its influence on other variables, which can be done using one of the AMOS program's outputs, the Standardized Total Effect. The following figure illustrates the magnitude of the influence of variables on each path coefficient. Based on Figure 4 it can be seen that the dimensions of the social capital construct consisting of trust, social norms, and social networks have direct and indirect relationships and influences. This relationship is illustrated through the trust variable, which directly influences the formation of social networks and adherence to social norms, which will then also affect the formation of social networks. The following is an explanation of the relationship formed:

1.Trust has a positive and significant effect on social networks that are formed directly or indirectly through intermediary variables of social norms with a total influence value of 0.646 . The greater the sense of trust that is owned, the more comprehensive the social network that will be formed, and the greater the community's obedience to applicable norms, which will also affect the formation of social networks.

2. Trust has a positive and significant effect on social norms in the Pujon Kidul Tourism Village community with an influence value of 0.607 . The greater the sense of trust held by the community, the greater the obedience to comply with applicable norms.

3. Social norms positively and significantly affect the social network formed in the Pujon Kidul Tourism Village community with an influence value of 0.316 . The higher the community's adherence to applicable norms, the wider the social network formed.

Pujon Kidul Tourism Village is one of the villages affected by the Covid-19 pandemic. Based on the results of the primary survey, the Covid-19 pandemic had an impact on the socio-economic activities of rural communities. The impact from an economic perspective is that in 2020 the village must experience a decrease in turnover by $45 \%$ or Rp. 7.88 billion from the previous year, the purchasing power of tourist visitors decreases, causing people who have businesses to experience a decrease in income by $45-50 \%$ every month, sales of agricultural products decreased by about $75 \%$. As a result, as many as 355 or around 250 tourism workers had to be laid off (Primary survey results, 2021). Meanwhile, the 
social impact is that the community is experiencing social disorganization due to the implementation of social distancing, which affects the community's socio-cultural activities such as nyandran, village cleaning, and ruwatan, which must be temporarily suspended (Primary survey results, 2021). The impact of the Covid-19 pandemic, particularly in the economic field, has compelled the village government and community to take action to combat the Covid-19 pandemic. Therefore, social capital and social values must be a firm grip (Mutiara et al., 2020). Social capital is a social life in which some participants take effective collective action to achieve common goals (Putnam, 2001). Currently, the condition of social capital owned by the Pujon Kidul Tourism Village people is considered to have become a firm grip for the community and the government to deal with the Covid-19 pandemic. This is shown through the results of the SEM analysis, which shows that social capital variables based on trust, social norms, and social networks have been able to have a positive and significant influence on each variable relationship (SEM Analysis Results, 2021). In addition, trust has a significant influence on the formation of community social capital (CFA Analysis Results, 2021).

Communities with a strong social capital level have a faster response in the short term to recover from a disaster or pandemic (Pitas and Ehmer, 2020). In addition, according to Jacobs and Hofman (2020), the existence of social capital in society is also seen as capable of forming a strong social cohesion and can encourage collective action. This is in response to the community's and village government's extraordinary response to the handling of Covid-19 in their village, which is manifested in the form of collective action. One form of collective action that comes from community initiatives is through social activities such as opening a free market during Large-Scale Social Restrictions (PSBB). Free market activities have a concept where people who have more income can put goods in necessities or other household needs in the market and can be taken freely for people in need. This free market activity is considered to help the community, especially for tourism activists who have to lose their jobs temporarily and for farmers who experience losses. Meanwhile, collective actions originating from the government in dealing with the Covid-19 pandemic include the following (Primary survey results, 2021).

- They are conducting routine socialization to comply with the Covid-19 health protocol.

- It was growing new creative economic activities that are realized through village-level programs, including training on planting organic systems to farmers, Training on making handicrafts, etc.

- Build a souvenirs center to market superior products produced from each RT (village neihbors) in the Pujon Kidul Tourism Village

The Pujon Kidul Tourism Village government's response to the Covid-19 pandemic in the form of joint action must, of course, be supported by the community. Based on the results of previous studies, it is stated that the condition of social capital is considered to have a significant impact on the success of disaster and pandemic management. Therefore, each party must work together as a form of disclosure of social capital (Regus, 2020). In addition, trust in the village government can significantly support the programs that have been created to deal with this pandemic. This trust is considered to contribute to the success of crisis handling and the sustainability of community preparedness in the future (Kustiningsih and Nurhadi, 2020). The Pujon Kidul Tourism Village community already has a high level of willingness to cooperate and a high level of trust in the village government (CFA Analysis Results, 2021). Therefore, if it is related to the research results of Regus (2020) and Kustiningsih and Nurhadi (2020), it can be seen that the Pujon Kidul Tourism Village government programs that have been created to handle the impact of the Covid-19 pandemic are assumed to be successful and goes well.

\section{CONCLUSION}

Conclusions from research studies related to "Social Capital of The Pujon Kidul Tourism Village Community in Facing the Covid-19 Pandemic" include the following:

1. The Pujon Kidul Tourism Village community's social capital comprises three variables: trust, social norms, and social networks. The trust variable is composed of five factors: trust in others (K1) with a value of 0.69 , trust in people from different cultural backgrounds (K2) with a value of 0.64 , trust in the village government (K3) with a value of 0.63 , trust in community leaders (K4) with a value of 0.50 , and trust in village institutions (K6) with a value of 0.50 . The social norm variable is formed from two factors, namely the level of obedience to the prevailing norms (N1) with a value of 0.70 and the level of attendance in participating in traditional activities or events (N2) 0.53. Meanwhile, the social network variable is formed by the willingness to work together to achieve mutual success (J1) with a value of 0.70 and the level of participation in community social activities (J3) with a value of 0.56 .

2. The most influential variable on the social capital formation of the Pujon Kidul Tourism Village community is the trust variable, with a value of 0.81 or $66.3 \%$. While social norms influence $55.5 \%$ and social networks influence $62.9 \%$.

3. Each social capital variable consisting of trust, social norms, and social networks has direct and indirect relationships and influences. This relationship is illustrated through the trust variable, which directly influences the formation of social networks and adherence to social norms, which will then also affect the formation of social networks.

4. The social capital of the Pujon Kidul Tourism village community is considered capable of being a solid grip for the community and the government in dealing with the Covid-19 pandemic. Strong social capital makes the community and the government have a response in the form of faster collective action. Several collective actions have been taken, including free markets, socialization, and programs to grow new creative economic activities. This action must be carried out with the cooperation of both parties, namely the government and the community. Based on the analysis results, the people of Pujon Kidul Tourism Village already have a high level of willingness to cooperate and have a high level of trust in the village government. So, when connected with the results of previous research, it can be assumed that the Pujon Kidul Tourism Village government programs that have been created to deal with the Covid-19 pandemic can be successful and run well.

\section{Acknowledgment}

This research was supported by the project, which has received funding from the Brawijaya University research program for Associate Professor Research Grant (Hibah Penelitian Lektor Kepala No. 31/UN10.F07/PN/2021). 


\section{REFERENCES}

Bourdieu, P. (1986). The Forms of Capital, Handbook of Theory and Research for the Sociology of Education, Westport, Connecticut, US. Collier, J.E. (2020). Applied Structural Equation Modeling Using AMOS, Routledge taylor \& Francis Group, New York.

Farisa, B.M.R., Prayitno, G., \& Dinanti, D. (2019). Social Capital and Community Participation on Infrastructure Development in Pajaran Village, Malang Regency Indonesia. IOP Conference Series: Earth and Environmental Science, 239(1).

Hauberer, J. (2011). Social Capital Theory Towards a Methodological Foundation, VS Research, Germany.

Huraerah, A. (2008). Pengorganisasian dan pengembangan masyarakat: model \& strategi pembangunan berbasis kerakyatan [Community organizing and development: people-based development models \& strategies], Humaniora, Bandung, Indonesia.

Ira, W.S., \& Muhamad, M. (2020). Partisipasi Masyarakat pada Penerapan Pembangunan Pariwisata Berkelanjutan (Studi Kasus Desa Wisata Pujon Kidul, Kabupaten Magelang) [Community Participation in the Implementation of Sustainable Tourism Development (Case Study of Pujon Kidul Tourism Village, Magelang Regency)]. Jurnal Pariwisata Terapan, 3(2), 124-135 (in Indonesian).

Irawati, H., Wicaksono, A.D., \& Prayitno, G. (2021). Modal Sosial dan Partisipasi Masyarakat dalam Kaitan Tingkat Kemajuan Desa [Social Capital and Community Participation in Relation to the Level of Village Progress]. Geography: Jurnal Kajian, Penelitian Dan Pengembangan Pendidikan, 9(1), 2-4 (in Indonesian).

Jacobs, E., \& Hofman, I. (2020). Aid, social capital and local collective action: Attitudes towards community-based health funds and village organizations in Rushan, Tajikistan. Community Development Journal, 55(3), 399-418.

Kustiningsih, W., \& Nurhadi, S. (2020). Tata Kelola Penanganan Covid-19 di Indonesia: Kajian Awal [Governance for Handling Covid-19 in Indonesia: A Preliminary Study], Gadjah Mada University Press, Yogyakarta, Indonesia.

Kusumastuti, A. (2015). Modal Sosial dan Mekanisme Adaptasi Masyarakat Pedesaan dalam Pengelolaan dan Pembangunan Infrastruktur [Social Capital and Adaptation Mechanisms of Rural Communities in Infrastructure Management and Development]. Masyarakat: Jurnal Sosiologi, 20(1) (in Indonesian).

Kwantes, C.T., \& Kuo, B.C.H. (2021). Trust and Trustworthiness across Cultures, Springer, Switzerland.

Leliana, D.H. (2017). Modal Sosial Masyarakat dalam Pengembangan Pariwisata (Studi Kasus: Destinasi Wisata Waduk Riam Kanan) [Community Social Capital in Tourism Development (Case Study: Riam Kanan Reservoir Tourism Destinations)], Undergraduate Thesis, Brawijaya University of Urban and Regional Planning Department, Malang, Indonesia.

Leon, D.S. (2020). Violence in the Barrios of Caracas. Social Capital and the Political Economy of Venezuela, Springer, Saxony, Germany.

Matei, D., Chiriță, V., \& Lupchian, M.M. (2021). Governance and tourism resilience during the COVID-19 crisis. Case study Bukovina, Romania. Geojournal of Tourism and Geosites, 34(1), 256-262.

Mutiara, I.A., Nur, S., Ramlan, H., \& Basra, M.H. (2020). Modal Sosial : Membangun Optimisme Sosial pada Masyarakat di Tengah Pandemi Covid - 19 [Social Capital: Building Social Optimism in the Community Amid the Covid-19 Pandemic]. Prosiding Seminar Nasional Problematika Sosial Pandemi Covid-19, 113-116 (in Indonesian).

Nugraha, A.T., Prayitno, G., Hasyim, A.W., \& Roziqin, F. (2021). Social capital, collective action, and the development of agritourism for sustainable agriculture in rural Indonesia. Evergreen, 8(1), 1-12. https://doi.org/10.5109/4372255

Ostrom, E., \& Ahn, T.K. (2007). The meaning of social capital and its link to collective action, Workshop in Political Theory and Policy Analysis, Bloomington, United States.

Pitas, N., \& Ehmer, C. (2020). Social Capital in the Response to COVID-19. American Journal of Health Promotion, 34(8), 942-944.

Prayitno, G., Ahari, M.I., \& Rukmi, W.I. (2021). Structural equation model with partial least square (SEM-PLS) of place dependence with land used change. Journal of International Studies, 14(1), 153-171.

Prayitno, G., Hakim, A.N., \& Meidiana, C. (2020). Factors influencing the willingness to join CBO biogas self-help group in Mulyorejo urban village and Karangnongko village in Malang, Indonesia. Evergreen, 7(4), 468-480.

Prayitno, G., Sari, N., \& Putri, I.K. (2019). Social capital in poverty alleviation through Pro-Poor Tourism concept in Slum Area (Case Study: Kelurahan Jodipan, Malang City). International Journal of GEOMATE, 16(55), 131-137. https://doi.org/10.21660/2019.55.37152

Putnam, R.D. (2001). Bowling alone: the collapse and revival of American community, Touchstone Books by Simon \& Schuster, New York.

Putnam, R.D., \& Goss, K.A. (2002). Democracies in Flux: The Evolution of Social Capital in Contemporary Society, Oxford University Press, New York.

Regus, M. (2020). Pentingnya Revitalisasi Modal Sosial Paska Pandemi Covid-19 [The Importance of Revitalizing Social Capital After the Covid-19 Pandemic]. Jurnal Kependudukan Indonesia, 11-13 (in Indonesian).

Roziqin, F. (2019). Modal Sosial Masyarakat Kaitannya dengan Keputusan dalam Tindakan Kolektif Pengembangan Desa Pujon Kidul [Community Social Capital Relation to Decisions in Collective Action for Pujon Kidul Village Development], Thesis, Brawijaya University of Urban and Regional Planning Department, Malang, Indonesia.

Santoso, S. (2014). Konsep Dasar dan Aplikasi SEM dengan AMOS 22 [Basic Concepts and Applications of SEM with AMOS 22], Elex Media Komputindo, Jakarta, Indonesia.

Setyosari, P. (2016). Metode Penelitian Pendidikan dan Pengembangan [Educational Research and Development Methods], Prenada Media, Jakarta, Indonesia.

SIE Pujon Kidul. (2020). Laporan Finansial BumDes Pujon Kidul [BumDes Pujon Kidul Financial Report], Report, Pujon Kidul Village Government, Malang, Indonesia.

Sidu, D. (2006). Model Pemberdayaan Masyarakat Sekitar Kawasan Hutan Lindung Jompi Kabupaten Muna, Provinsi Sulawesi Tenggara [Community Empowerment Model Around the Jompi Protected Forest Area, Muna Regency, Southeast Sulawesi Province], Dissertation, Bogor Agricultural Institute of Development Extension, Bogor, Indonesia.

Suaib, H. (2017). Nilai - Nilai Kearifan Lokal dan Modal Sosial dalam Pemberdayaan Masyarakat Suku Moi [Values of Local Wisdom and Social Capital in Empowering the Moi Tribe Community], An1mage, Tanggerang, Indonesia.

Supriadi, B., \& Roedjinandari, N. (2017). Perencanaan dan Pengembangan Destinasi Pariwisata (Vol. I) [Tourism Destination Planning and Development (Vol. I)], Universitas Negeri Malang Press, Malang, Indonesia.

Syahra, R. (2003). Modal sosial: Konsep dan aplikasi [Social capital: Concepts and applications]. Jurnal Masyarakat Dan Budaya, 5(1), 1-22 (in Indonesian).

Tiyasmono, D.K., Riyanti, G.A., \& Hardianto, F.N. (2019). Model Konseptual Hubungan Modal Sosial dan Kinerja BUMDes [Conceptual Model of the Relationship of Social Capital and BUMDes Performance]. Management Dynamic Conference 5 (MADIC 5), 214-220 (in Indonesian).

Trisnanto, T.B., Fitriani, \& Fatih, C. (2017). Building social capital for farmer association [Building social capital for farmer association]. Masyarakat, Kebudayaan dan Politik, 30(10), 59-67.

Zamroni, A.B. (2018). Modal Sosial Dalam Pelaksanaan Program Desa Mandiri Pangan Di Desa Ngadirojo Kabupaten Pacitan [Social Capital in the Implementation of the Food Independent Village Program in Ngadirojo Village, Pacitan Regency], Undergraduate Thesis, Brawijaya University of Urban and Regional Planning Department, Malang, Indonesia. 